\section{MYCORRHIZAL ASSOCIATION OF OCHLANDRA TRAVANCORICA IN KERALA, INDIA}

\author{
P.P. Rajeshkumar ${ }^{1}$, V.B. Hosagoudar ${ }^{2}$ \& B. Gopakumar ${ }^{3}$
}

1,2,3 Jawaharlal Nehru Tropical Botanic Garden and Research Institute, Palode, Thiruvananthapuram, Kerala 695562, India

${ }^{1}$ pprajeshkumar1981@gmail.com, ${ }^{2}$ vbhosagoudar@rediffmail.com (corresponding author), ${ }^{3}$ gopugokulam@rediffmail.com

Terminal feeder roots and rhizosphere soil samples of the Reed Bamboo Ochlandra travancorica were collected in July 2011 from different localities in Kollam and Thiruvananthapuram districts of Kerala State. Composite soil samples (Soil pH 3.9-5.6.) revealed the presence of nine AM fungal taxa, namely, Claroideoglomus etunicatum, Glomus aggregatum, G. boreale, G. macrocarpum, G. multicaule, G. tortuosum, Sclerocystis clavispora, S. rubiformis and S. taiwanensis. Root colonization was $42-72 \%$ and extensive hyphal and vesicular stages were observed. The extra-radical hyphae were hyaline and dichotomously branched on root epidermis showed appressoria. The hyphal coils were observed in the cortex cells.

The Reed Bamboo is one of the most important sources of raw material for the paper and pulp industry, traditional cottage industries and is widely distributed in the Kerala State in Western Ghats. The genus Ochlandra represents seven species and a variety (Image 1a). Ochlandra travancorica Benth. ex Gamble is a big size reed occurring widely as an undergrowth in the low level evergreen and semi-evergreen forests. Pure patches on the banks of rivers and streams form impenetrable thickets where other tree species cannot grow but also occurs in abandoned cultivated land. The species grows profusely in southern Kerala, especially in the forests of Thiruvananthapuram, Thenmala and Ranni. It prefers diffused light, requires annual rainfall of more than $1500 \mathrm{~mm}$ and good drainage for its luxuriant growth. The perfect growth and regeneration of these valuable plants in its restricted habit and habitat is presumed to be because of certain microbes, especially mycorrhizal fungi.

Materials and Methods: The feeder roots and rhizosphere soil samples of Ochlandra travancorica were collectedfromfoursites (Bonacaud, Kottoor, Kulathupuzha and Palode) of Kollam and Thiruvananthapuram districts in Kerala in July 2011. Four soil samples were taken from each site up to the depth of $20 \mathrm{~cm}$ and prepared into one composite sample (ca. $500 \mathrm{gm})$. The soil was screened to isolate Arbuscular Mycorrhizal (AM) fungal spores by wet-sieving and decanting technique and the count expressed as spores per $100 \mathrm{~g}$ of soil (Gerdemann \& Nicolson 1963).

Terminal feeder root samples collected from a different area was processed separately; washed in running tap water, cut into small pieces about $1 \mathrm{~cm}$, boiled in $10 \% \mathrm{KOH}(\mathrm{w} / \mathrm{v})$ for one hour, cooled to room temperature, washed thoroughly in distilled water, stained in lactophenol cotton blue (Philips \& Hayman 1970). They were observed under a binocular microscope to locate vesicles and arbuscules to evaluate the percentage of mycorrhizal colonization.

$\begin{array}{ll}\begin{array}{l}\text { Percentage of mycorrhizal } \\ \text { colonization }\end{array} & \begin{array}{l}\text { No. of mycorrhizal root segments } \\ \text { Total no. of root segment observed }\end{array}\end{array}$

The frequency of occurrence of AM fungi was calculated by using the formula:

DOI: http://dx.doi.org/10.11609/JoTT.o3235.3673-77

Editor: H.C. Nagaveni, Institute of Wood Science and Technology, Bengaluru, India.

Date of publication: 26 February 2013 (online \& print)

Manuscript details: Ms \# 03235 | Received 13 June 2012 | Final received 10 January 2013 | Finally accepted 14 February 2013

Citation: Rajeshkumar, P.P., V.B. Hosagoudar \& B. Gopakumar (2013). Mycorrhizal association of Ochlandra travancorica in Kerala, India. Journal of Threatened Taxa 5(2): 3673-3677; doi:10.11609/JoTT.03235.3673-77.

Copyright: (c) Rajeshkumar et al. 2013. Creative Commons Attribution 3.0 Unported License. JoTT allows unrestricted use of this article in any medium, reproduction and distribution by providing adequate credit to the authors and the source of publication.

Funding: Jawharlal Nehru Tropical Botanic Garden \& Research Institute, Palode.

Competing Interest: None

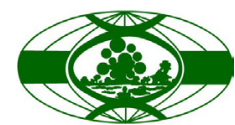

Acknowledgements: We thank Dr. P.G. Latha, Director and Dr. K.C. Koshy, Senior Scientist, JNTBGRI, Palode for the facilities and for generously permitting us to use the soil samples, respectively. We thank the head, Department of Agronomy, College of Agriculture, Kerala Agricultural University, Vellayani, Thiruvananthapuram. 
The frequency $(\%)=\frac{\text { Sample unit in which fungal species occurred }}{\text { Total number sample units examined }}$

Numerical species richness was used in the present study. Index of general diversity $\left(\mathrm{H}^{\prime}\right)$ was calculated by Shannon \& Weaver (1949) cited in Odum (1971).

$$
H^{\prime}=\Sigma\left(n_{i} / \operatorname{Nog}_{e} n_{i} / N\right)
$$

where, $n_{i}$ is the importance value of each species and $N$ is the total importance value.

Index of dominance (C) (Simpson 1949).

$$
\mathrm{C}=\Sigma(\mathrm{ni} / \mathrm{N})
$$

where $n_{i}$ is the number of individuals of each species and $\mathrm{N}$ is the total number of individuals in that location.

The fungal spores were identified with the help Schenk \& Perez (1990).

The soil from different sampling sites was analyzed for soil fertility such as $\mathrm{pH}$ (Eutech instruments $\mathrm{pH}$ tutor), electric conductivity (Eutech instruments), organic carbon (Walkley \& Black's rapid titration method 1934), total nitrogen micro-Kjeldahl method (Jackson 1973), available phosphorous (Bray \& Kurtz 1945) and available potassium was estimated by ammonium acetate method (Hanway \& Heidel 1952) using flame photometer (Systronic 3292).

\section{Result}

Hyphal structure: The root samples exhibited the presence of extensive hyphal and vesicular stages of AM fungal colonization and the colonization varied from $42-72 \%$. The extra-radical hyphae were hyaline and dichotomously branched on root epidermis to form an appressoria. The hyphae on the root were hyaline to yellowish-brown, thick-walled, aseptate, growing inter and intra cellularly through the cortex and had penetrated the inner cortex. The hyphal coils were observed in root cortex and globose to subglobose terminal vesicles $(25-37 \times 25-40 \mu \mathrm{m}$; Image 1 b) were observed in the cortex cells.

Spore count: Arbuscular mycorrhizal fungi were found to be present in all the sampling sites in this study and spore count was 272-348 spores per 100g soil (Fig. 1). A total of nine species, namely, Claroideoglomus etunicatum, Glomus aggregatum, G. boreale, G. macrocarpum, G. multicaule, G. tortuosum, Sclerocystis clavispora, S. rubiformis, S. taiwanensis were isolated from the different sampling areas. Among these, $G$. aggregatum, S. clavispora and S. rubiformis were common to all the sites.

The frequency of occurrence of mycorrhizal species associated with $O$. travancorica varied from one locality

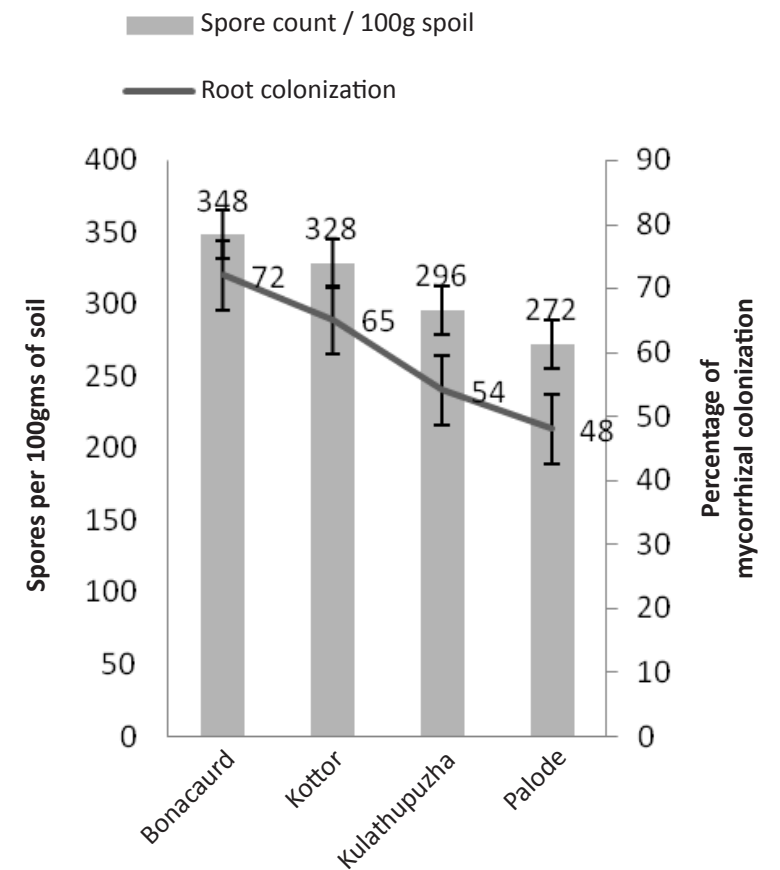

Figure 1. Arbuscular mycorrhizal fungal root colonization and spore count per $100 \mathrm{~g}$ soil of different habitats of Ochlandra travancorica

to another (Table 1). G. aggregatum, S. clavispora and $S$. rubiformis were found in all the locations of the study; whereas, incidence of G. macrocarpum was $75 \%$ and $G$. boreale, G. tortuosum and S. taiwanensis was $50 \%$, Claroideoglomus etunicatum and G. multicaule showed $25 \%$ of frequency. Species richness also varied. Kulathupuzha harboured more number of species than the other study localities. Simpson's diversity index (Ds) and Shannon's diversity index (Hs) was in the range of 0.6-0.8 and 2.8-4.4, respectively.

Physiochemical characters of soil: The $\mathrm{pH}$ of $O$. travancorica rhizosphere soils collected from the study sites was 3.9-5.6. The level of phosphorous was very low. The physiochemical characters of soil samples are in the Table 2.

\section{Description of the species \\ Claroideoglomus etunicatum (Image 1c)}

(W.N. Becker \& Gerd.) C. Walker \& A. Schüßler Gloucester, p. 22, 2010.

Glomus etunicatum W.N. Becker \& Gerd., Mycotaxon 6(1): 29, 1977.

Material examined: 25.vii.2011, isolated from rhizosphere soil of Ochlandra travancorica, Kulathupuzha, coll. P.P. Rajesh Kumar (TBGT slide no. 1020).

Chlamydospores formed singly in soil or in dead roots, adherent to debris, globose to subglobose, 70-135 $\mu \mathrm{m}$ in diam., wall smooth to roughened. Spore wall 4-10 
Table 1. Pattern of species richness and relative frequency of AM fungi in different habitats of Ochlandra travancorica

\begin{tabular}{|l|c|c|c|c|c|}
\hline AM fungal Species & Bonacaurd & Kottor & Kulathupuzha & Palode & Relative frequency \% \\
\hline Claroideoglomus etunicatum & - & - & + & - & 25 \\
\hline Glomus aggregatum & + & + & + & + & 100 \\
\hline Glomus boreale & - & & + & + & 50 \\
\hline Glomus macrocarpum & + & + & + & - & 75 \\
\hline Glomus multicaule & - & - & + & - & 25 \\
\hline Glomus tortuosum & - & - & + & + & 50 \\
\hline Sclerocystis clavispora & + & + & + & + & 100 \\
\hline Sclerocystis rubiformis & + & + & + & + & 100 \\
\hline Sclerocystis taiwanensis & + & + & - & - & 50 \\
\hline Spices richness & 5 & 5 & 8 & 5 & \\
\hline
\end{tabular}

$=$ presence $-\mathbf{~ = ~ a b s e n c e ~}$

Table 2. Soil chemical properties of Ochlandra travancorica habitats studied

\begin{tabular}{|c|c|c|c|c|c|c|}
\hline Sampling area & $\mathrm{PH}$ & $\begin{array}{l}\text { Electrical conductivity } \\
\qquad(\mathrm{ds} / \mathrm{m})\end{array}$ & $\begin{array}{l}\text { Organic carbon } \\
(\mathrm{kg} / \mathrm{ha})\end{array}$ & $\begin{array}{c}\text { Available nitrogen } \\
\text { (kg/ha) }\end{array}$ & $\begin{array}{c}\text { Available phosphorus } \\
\text { (kg/ha) }\end{array}$ & $\begin{array}{c}\text { Available potassium } \\
\text { (kg/ha) }\end{array}$ \\
\hline Bonacaud & 4.4 & 0.3 & 2.96 & 326.14 & 0.12 & 449.63 \\
\hline Kottor & 4.4 & 0.4 & 2.93 & 346.55 & 0.18 & 528.32 \\
\hline Kulathupuzha & 5.6 & 0.5 & 0.78 & 250.88 & 0.15 & 589.93 \\
\hline Palode & 3.9 & 0.2 & 0.88 & 275.97 & 0.56 & 102.14 \\
\hline
\end{tabular}

$\mu \mathrm{m}$ thick, outer wall hyaline, up to $5 \mu \mathrm{m}$ thick, inner wall persistent, yellow to brown, laminated 2-8 $\mu$ m thick. Intact outer wall rarely present in matured spores. Hyphal attachments to spores are one; outer wall extending down up to attached hypha for a short distance. Attached hypha thickened by extension of inner spore wall for up to $30 \mu \mathrm{m}$, spore contents separated from attached hypha by a thin curved septum at maturity, opening occluded by inner wall thickening.

\section{Glomus aggregatum (Image 1d)}

Schenck \& Smith emend. Koske, Mycologia 74(1): 80, 1982.

Materials examined: 25.vii.2011, isolated from rhizosphere soil of Ochlandra travancorica, Kulathupuzha, coll. P.P. Rajesh Kumar (TBGT slide no. 1041); 25.vii.2011, Palode (TBGT slide no. 1077); 20.vii.2011, Bonacaud, (TBGT slide no. 1088); 22.vii.2011, Kottur, TBGT slide no. 1090.

Chlamydospores formed in loose clusters, without peridium, hyaline to yellow, globose, subglobose, obovate, cylindrical to irregular, 40-90 x 45-110 $\mu \mathrm{m}$; wall yellow to yellowish-brown, up to $2 \mu \mathrm{m}$ thick, outer walls slightly thicker and lighter in colour than the inner wall; walls separable with slight pressure. Subtending hyphae at the point of attachment was $4-10 \mu \mathrm{m}$ wide, straight to sharply curved at the spore base. Pore usually open, $2-5 \mu \mathrm{m}$ wide, often closed by a thin curved septum, cytoplasmic plug or spore wall thickening but not by hyphal wall thickening.

\section{Glomus boreale (Image 1e)}

(Thaxt.) Trappe \& Gerd., in Gerd. \& Trappe, Mycol. Mem. 5: 58, 1974 (borealis).

Endogone borealis Thaxt., Proc. Amer. Acad. Arts \& Sci. 57: 318, 1922.

Material examined: 25.vii.2011, isolated from rhizosphere soil of Ochlandra travancorica, Kulathupuzha, coll. P.P. Rajesh Kumar (TBGT slide no. 1033); 27.vii.2011, Palode, coll. B. Gopakumar (TBGT slide no. 1051).

Chlamydospores mass irregular, spongy, dark to chocolate brown, 6-8 $\mathrm{mm}$ in diameter. Gleba with loosely woven hyphae, 10-18 $\mu \mathrm{m}$ broad, contains foreign matter and many abortive spores. Spores borne on slender hyphae and subtended by the septum, reddish-brown, broadly and symmetrically elliptical, 128-142 x 98-106 $\mu \mathrm{m}$ in diam., wall reddish-brown, up to $8 \mu \mathrm{m}$ thick.

\section{Glomus macrocarpum (Image 1f)}

Tul. \& C. Tul., G. Bot. Ital. 1(7-8): 63, 1845 (macrocarpus).

Endogone macrocarpa (Tul. \& C. Tul.) Tul. \& C. Tul., Fungi Hypog.: 182, 1851. 


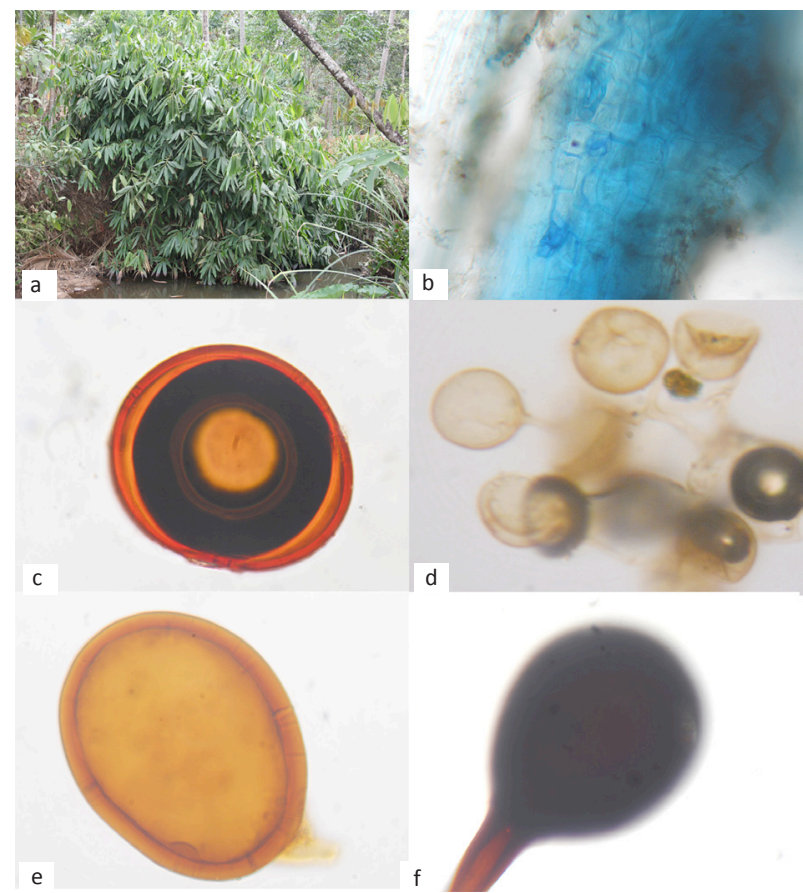

Image 1. a - Habitat of Ochlandra travancorica Benth. ex Gamble; b - Vesicles inside cortical cells; c - Claroideoglomus etunicatum (W.N. Becker \& Gerd.); d - Walker \& A. Schüßler; e - Glomus aggregatum Schenck \& Smith emend. Koskee; f - Glomus boreale (Thaxt.) Trappe \& Gerd.

Material examined: 25.vii.2011, isolated from rhizosphere soil of Ochlandra travancorica, Kulathupuzha, coll. P.P. Rajesh Kumar (TBGT slide no. 1023); 20.vii.2011, Bonacaud, coll. P.P. Rajesh Kumar (TBGT slide no. 10 99); 25.vii.2011, 22.vii.2011, Kottur, coll. P.P. Rajesh Kumar TBGT slide no. 1102).

Chlamydospores slightly longer than wide, globose, subglobose to irregular, 98-130 x 98-130 $\mu \mathrm{m}$. Spore wall composed of two layers, outer layers thin up to $\mu \mathrm{m}$ thick; inner wall layer yellow, 6-10 $\mu \mathrm{m}$ thick. Spores taper to the point of attachment, hypha single, persistent, $12 \mu \mathrm{m}$ broad at this point of attachment, inner wall occlude the pore of the attached hyphae, and the wall thickening continuous in to the subtending hyphae for up to $75 \mu \mathrm{m}$ from the spore. Pore closed by a septum. Spores characteristically bear straight, long subtending hyphae which may extend up to $100 \mu \mathrm{m}$ before branching.

\section{Glomus multicaule (Image 2a)}

Gerd. \&Bakshi, Trans. Brit. Mycol. Soc. 66(2): 340, 1976 (multicaulis).

Material examined: 25.vii.2011, isolated from rhizosphere soil of Ochlandra travancorica, Kulathupuzha, coll. P.P. Rajesh Kumar (TBGT slide no. 1018).

Sporocarps unknown; chlamydospores dark brown,
142-240 x 125-150 $\mu \mathrm{m}$ in diam., ellipsoidal, broadly ellipsoidal, subglobose to occasionally triangular, with 1-4 hyphal attachments, attachments generally occurring at opposite ends of the spore. Spore wall 8-22 $\mu \mathrm{m}$ thick, thickest at the point of hyphal attachments, rounded projections 1-3 $\mu \mathrm{m}$ long, evenly distributed over the wall surface.

\section{Glomus tortuosum (Image 2b)}

N.C. Schenck \& G.S. Sm., Mycologia 74(1): 83, 1982.

Parapseudoglomus tortuosum (N.C. Schenck \& G.S. Sm.) S.P. Gautam \& U.S. Patel, The Mycorrhizae: Diversity, Ecology and Applications, p. 11, 2007.

Sporocarps unknown, chlamydospores formed singly or in pairs in soil, immature spores subhyaline, without hyphal mantle. Matured spores yellow to dull greyishbrown with a mantle of sinuses hyphae closely apprised to the spore and flattened, 4-10 $\mu \mathrm{m}$ wide, forming a layer of hyphae on the spore surface, up to $20 \mu \mathrm{m}$ thick, occasionally mantle extended down to the hyphal attachment. Mantle hyphae hyaline when young, acquiring a brownish pigment with age and originating from the swelling on the hyphal attachment, 10-20 $\mu \mathrm{m}$ below the spore or arising from the other hyphae adjacent to the spore. Mantle adhered with debris and soil particles. Chlamydospores globose to subglobose, 120-210 $\mu \mathrm{m}$ (excluding mantle); spores with single laminate thin wall less than $1 \mu \mathrm{m}$. The width of hyphal attachment at the spore base is $8-20 \mu \mathrm{m}$, hyaline to light yellow.

Material examined: 25.vii.2011, isolated from rhizosphere soil of Ochlandra travancorica, Kulathupuzha, coll. P.P. Rajesh Kumar (TBGT slide no. 1062); 27.vii.2011, Palode, coll. P.P. Rajesh Kumar (TBGT slide no. 1097).

\section{Sclerocystis clavispora (Image 2c)}

Trappe, Mycotaxon 6(2): 359, 1977.

Material examined: 27.vii.2011, isolated from rhizosphere soil of Ochlandra travancorica, Palode, coll. P.P. Rajesh Kumar (TBGT slide no. 1068); 25.vii.2011, Kulathupuzha, coll. P.P. Rajesh Kumar (TBGT slide no. 1072); 20.vii.2011, Bonacaud, P.P. Rajesh Kumar (TBGT slide no. 1073); 22.vii.2011, Kottur, coll. P.P. Rajesh Kumar (TBGT slide no. 1074).

Sporocarps globose to subglobose, 400-710 x 500$710 \mu \mathrm{m}$, brownish-black to black, minutely verrucose, spores formed radially in a single, tightly packed layer around a central plexus of hyphae; peridium lacking. Chlamydospores brown, $142-180 \times 20-38 \mu \mathrm{m}$, clavate to subcylindrical, tapering towards hyphal attachment, hyphal attachment 7-10 $\mu \mathrm{m}$ broad. Spore wall 1-3 $\mu \mathrm{m}$ thick at the sides, 17-22 $\mu \mathrm{m}$ thick at the apex, 5-8 $\mu \mathrm{m}$ 


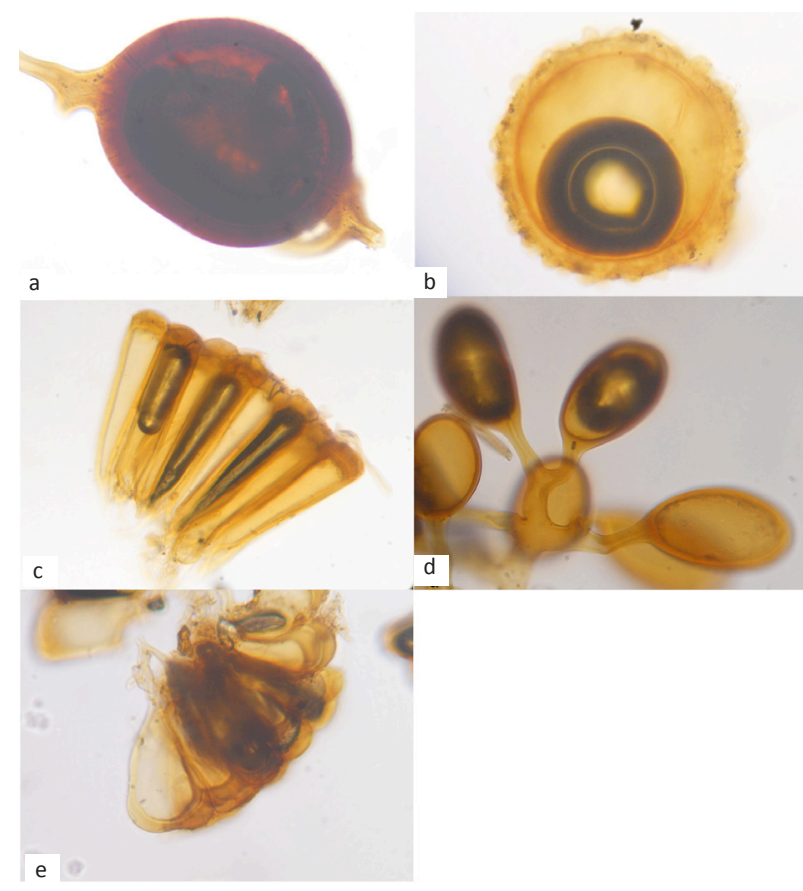

Image 2. a - Glomus multicaule Gerd. \& Bakshib.; b - Glomus tortuosum N.C. Schenck \& G.S.Sm.; c - Sclerocystis clavispora Trapped; d - Sclerocystis rubiformis Gerd. \& Trappee; e - Sclerocystis taiwanensis C.G. Wu \& Z.C. Chen.

thick at the base. Central plexus $145-440 \mu \mathrm{m}$ in diam., composed of tightly interwoven, pale brown, thin walled hyphae of 3-8 $\mu \mathrm{m}$ broad.

\section{Sclerocystis rubiformis (Image 2d)}

Gerd. \& Trappe, Mycol. Mem. 5: 60, 1974.

Glomus rubiforme (Gerd. \& Trappe) R.T. Almeida \& N.C. Schenck, Mycologia 82(6): 709, 1990.

Sclerocystis indica Bhattacharjee \& Mukerji in Bhattacharjee, Mukerji \& Misra, Acta Bot. Indica 8(1): 99, 1980.

Sclerocystis pachycaulis C.G. Wu \& Z.C. Chen, Taiwania 31: 74, 1986.

Material examined: 25.vii.2011, Isolated from rhizosphere soil of Ochlandra travancorica, Kulathupuzha, coll. P.P. Rajesh Kumar (TBGT slide no. 1030); 20.vii.2011, Bonacaud, coll. P.P. Rajesh Kumar (TBGT slide no. 1032); 27.vii.2011, Palode, coll. P.P. Rajesh Kumar (TBGT slide no. 1046); 22.vii.2011, Kottur, coll. P.P. Rajesh Kumar (TBGT slide no. 1057).

Sporocarps dark brown, subglobose to ellipsoid, 180-370 x 180-370 $\mu \mathrm{m}$, consisting of a single layer of chlamydospores surrounding a central plexus of hyphae, resembling a miniature blackberry. Peridium nearly absent, individual spores at times partially enclosed in a thin network of tightly appressed hyphae. Chlamydospores dark brown, obovoid, ellipsoid to subglobose, 32-110 x 24-80 $\mu \mathrm{m}$ with a small pore opening into the thick walled subtending hypha. Spore wall laminate, 3-8 $\mu \mathrm{m}$ thick, up to $13 \mu \mathrm{m}$ thick at spore base, often perforated projections on the inner surface. A variable stalk-like projection produced near the base of some spores.

\section{Sclerocystis taiwanensis (Image 2e)}

C.G. Wu \& Z.C. Chen, Trans. Mycol. Soc. Rep. China 2(2): 78, 1987; Shaji, Rajeshkumar \& Hosag., Indian J. Bot. Res. 5 (1\&2): 125-126.

Glomus taiwanense (C.G. Wu \& Z.C. Chen) R.T. Almeida \& N.C. Schenck, Mycologia 82(6): 711, 1990.

Glomus taiwanense (C.G. Wu \& Z.C. Chen) R.T. Almeida \& N.C. Schenck ex Y.J. Yao, in Yao, Pegler \& Young, Bull. 50(2): 306, 1995.

Material examined: 20.vii.2011, isolated from rhizosphere soil of Ochlandra travancorica, Bonacaud, coll. P.P. Rajesh Kumar (TBGT slide no. 1079); 22.vii.2011, Kottur, coll. P.P. Rajesh Kumar (TBGT slide no. 1080).

Sporocarps globose, brown to dark brown, 190-250 x 190-250 $\mu \mathrm{m}$ in diameter. Chlamydospores formed radially in a single, tightly packed layer around the central plexus of hyphae, clavate to cylindrical, cinnamon brown, 65-80 $\mu \mathrm{m}$ long, 28-32 $\mu \mathrm{m}$ broad at the upper portion, 9-18 $\mu \mathrm{m}$ broad at the lower portion, with or wit out septum at spore base. Wall two-layered, external one thin and hyaline, inner layer brown, apical portion of the wall deep golden brown, 9-13 $\mu$ m thick, 2-3 $\mu$ m thick laterally. Central portion pale yellow and typically distinct from the wall. Stalk pale brown, continuous, 9-22 x 2-4 $\mu \mathrm{m}$, central plexus up to $70 \mu \mathrm{m}$ in diameter.

\section{REFERENCES}

Bray, R.H. \& L.T. Kurtz (1945). Determination of total organic carbon and available forms of phosphorus in soils. Soil Science 59: 39-45

Gerdemann, J.W. \& T.H. Nicolson (1963). Spores of mycorrhizal Endogone species extracted from soil by wet sieving and decanting. Transactions of the British Mycological Society 46: 235244.

Hanway, J.J. \& H. Heidal (1952). Soil analysis method as used in lowa State College Soil TestingLaboratory. lowa Agriculture 57: 1-31.

Jackson, M.L. (1973). Soil Chemical Analysis. Prentice Hall of India, New Delhi, 239pp.

Odum, E.P. (1971). Fundamentals of Ecology-3rd Edition. W.B. Saundersand Co, Tokyo.

Philips, J.M. \& D.S. Hayman (1970). Improved procedures for clearing roots and staining parasitic and vesicular-arbuscular mycorrhizal fungi for rapid assessment of infection. Transactions of the British Mycological Society 55: 158-161.

Schenk, N.C. \& Y. Perez (1990). Manual for the Identification of VA Mycorrhizal Fungi. Synergistic Publications, USA, 286pp.

Simpson, E.H. (1949). Measurement of diversity. Nature 163:688

Walkley, A.J. \& I.A Black (1934). Estimation of soil organic carbon by chromic acid titration method. Soil Science 37: 29-38. 